\title{
ANALISIS PENGARUH RASIO PROFITABILITAS TERHADAP KEMAMPUAN PERUSAHAAN UNTUK MENGELUARKAN ZAKAT
}

\author{
Faisal Hidayat $^{1}$ \&Miftahurrahmah ${ }^{2}$ \\ ${ }^{1 \& 2}$ Institut Agama Islam Sumatera Barat (IAI SUMBAR) Pariaman \\ Email :faisalhidayat@iaisumbar.ac.id,miftahurrahmahmfh@gmail.com
}

\begin{abstract}
ABSTRAK
Perbankan syariah merupakan representasi dari sistem ekonomi Islam yang menegaskan secara ekplisit dan tegas orientasi sosial di dalamnya. Salah satu fungsi sosial tersebut adalah zakat. Pada bank syariah, orientasi akan zakat berbanding lurus terhadap profitabilitas perusahaan tersebut karena untuk meningkatkan kemampuan zakat bank syariah terlebih dahulu meningkatkan profitabilitasnya. Tujuan dari penelitian ini untuk menganalisis pengaruh Rasio Profitabilitas terhadap tingkat kemampuan pengeluaran zakat pada Bank Syariah Devisa dengan proksi dari Rasio Profitabilitas yakni Return On Asset (ROA) dan Return On Equity (ROE). Data dari penelitian ini berasal dari laporan keuangan tahunan (Annual Report) PT. Bank Muamalat Indonesia, PT. Bank BNI Syariah, PT. Bank Syariah Mandiri, dan PT. Bank Mega Syariah dari tahun 2014 sampai tahun 2017. Adapun untuk variabel penelitian yang digunakan adalah zakat sebagai variabel dependen sedangkan variabel independen adalah Return On Asset (ROA) dan Return On Equity (ROE). Penelitian ini menggunakan regresi data panel dengan menggunakan Eviews 9 sebagai alat analisis. Setelah dilakukan analisis, hasil dari penelitian ini membuktikan bahwa Return On Asset tidak berpengaruh terhadap kemampuan pengeluaran zakat, sedangkan Return On Equity mempengaruhi kemampuan pengeluaran zakat.
\end{abstract}

Kata kunci : Zakat, Return On Asset (ROA), dan Return On Equity (ROE).

\begin{abstract}
Islamic banking is a representation of the Islamic economic system that confirms explicitly and firmly the social orientation within it. One such social function is zakat. In sharia banks, the orientation of zakat is directly proportional to the profitability of the company due to increase the zakat ability of sharia bank, first improve its profitability. The purpose of this study is to analyze the influence of Profitability Ratio to the level of zakat expenditure capability in Sharia Bank Foreign exchange with proxy from Profitability Ratio is Return On Asset (ROA) and Return On Equity (ROE). Data from this research comes from Annual Report of PT. Bank Muamalat Indonesia, PT. Bank BNI Syariah, PT. Bank Syariah Mandiri and PT.Bank Mega Syariah from 2014 until 2017. As for the variable of research used is Zakat as dependent variable while independent variable is Return On Asset (ROA) and Return On Equity (ROE). This study uses panel data regression using Eviews 9 as an analytical tool. After the analysis, this study proves that Return On Asset does not affect the ability of zakat expenditure, while Return On Equity affect the ability of zakat expenditure
\end{abstract}

Keywords : Zakat, Return On Asset (ROA), dan Return On Equity (ROE). 


\section{PENDAHULUAN}

Pada tahun 1992, Bank syariah secara resmi pertama kali diperkenalkan dengan berlakunya Undang-Undang No. 7 tahun 1992 tentang perbankan. Lahirnya Undang-Undang ini merupakan landasan operasional perbankan, namun UndangUndang ini belum memberikan landasan hukum yang cukup kuat terhadap pengembangan perbankan syariah dikarenakan mengenai keberadaan bank berdasarkan prinsip syariah belum diatur secara tegas melainkan bank bagi hasil. Kemudian Bank Indonesia (BI) mengubah Undang-Undang ini dengan UU No. 10 tahun 1998 dengan pertimbangannya adalah untuk mengantisipasi tantangan sistem keuangan yang semakin maju dan kompleks mempersiapkan infrastruktur memasuki era globalisasi (Rofiq, 2021).

Sampai saat ini bank syariah semakin menunjukkan eksistensinya di tengah-tengah lembaga keuangan lainnya semenjak diperkenalkannya pertama kali di Indonesia pada tahun 1992. Hal tersebut merupakan bukti bahwa pada di tengah gelombang krisis ekonomi pada pertengahan tahun 1997, lembaga keuangan yang beroperasi dengan prinsip syariah mampu bertahan dalam keadaan tersebut. Sebagai lembaga intermediasi, kehadiran bank syariah menjadi solusi alternatif bagi para pelaku ekonomi kecil dan menengah yang memang menjadi target operasionalnya (Iswanaji et al, 2021).

Berdasarkan pasal 5 UndangUndang No. 10 tahun 1998 tentang perbankan, terdapat dua jenis bank yaitu Bank Umum dan Bank Perkreditan Rakyat. Dalam kegiatan usahanya, kedua jenis bank tersebut diklasifikasikan menjadi dua yaitu bank konvensional dan bank syariah. Berbeda dengan bank konvensional, bank syariah adalah bank yang beroperasi dengan tidak mengandalkan pada bunga. Bank syariah merupakan lembaga keuangan perbankan yang operasional dan produknya dikembangkan berlandaskan pada AlQur'an dan Hadist. Dengan kata lain, Bank umum syariah adalah bank yang melakukan kegiatan usaha atau beroperasi berdasarkan prinsip syariah dan tidak mengandalkan pada bunga dalam memberikan pembiayaan dan jasa-jasa lainnya dalam lalu lintas pembayaran Prinsip syariah adalah aturan perjanjian berdasarkan hukum Islam antara pihak bank dan pihak lain untuk penyimpanan dana dan pembiayaan kegiatan usaha berdasarkan syariat Islam (Hasbi \& Amin, 2021).

Guna memaksimalkan jangkauan bank syariah baik dari segi funding maupun lending, Bank Indonesia telah mengizinkan bank syariah beroperasi sebagai bank devisa. Bank umum syariah yang telah resmi beroperasi sebagai Bank Umum Swasta Nasional (BUSN) Devisa yaitu Bank Syariah Mandiri, Bank BNI Syariah, Bank Mega Syariah, dan Bank Muamalat. Bank devisa adalah bank yang dapat mengadakan transaksi internasional seperti ekspor dan impor, jual beli valuta asing, dan lain sebagainya sesuai dengan ketentuan Bank Indonesia. Dengan demikian, bank devisa akan lebih mudah dan lebih banyak mendapatkan kesempatan untuk memaksimalkan dalam menyerap dan menyalurkan dana. Dengan mudahnya aksesdan kesempatan terhadap penyerapan dan penyaluran dana, maka kinerja bank devisa harusnya lebih baik dari bank non devisa. Bank non devisa belum mempunyai izin untuk melaksanakan transaksi sebagai bank devisa sehingga tidak dapat melaksanakan transaksi seperti halnya bank devisa (Antonio, 2005).

Seperti diketahui, bank syariah merupakan salah satu lembaga keuangan yang kegiatan usahanya disesuaikan dengan prinsip syariah Islam (Muhammad, 2005). Pendirian lembaga 
keuangan yang berlandaskan etika prinsip syariah atau sistem ekonomi Islam memiliki tujuan utama yaitu sebagai upaya kaum muslimin untuk mendasari segenap aspek kehidupan ekonominya berlandaskan Al-Qur'an dan As-Sunnah (Antonio, 2005).

Ekonomi Islam ini memiliki tujuan akhir sebagaimana tujuan dari syariat Islam itu sendiri atau Maqashid Asy Syariah yaitu mencapai kebahagiaan dunia dan akhirat melalui tata kehidupan yang baik dan terhormat atau hayyah thayyibah. Disamping sistem operasi bank syariah yang menawarkan berbagai produk yang bertujuan untuk mendapatkan keuntungan (profit oriented), yakni produk penghimpunan dana nasabah, produk penyaluran dana, dan produk jasa (Muhammad, 2005), konsep perbankan Islam juga mengharuskan bank Islam melaksanakan jasa sosial, bisa melalui dana qardhul hasan (pinjaman kebajikan), zakat, atau dana sosial yang sesuai dengan ajaran Islam (sosial oriented). Aspek sosial juga menjadi salah satu perbedaan mendasar antara bank syariah dengan bank konvensional. Pada bank syariah, aspek sosial dinyatakan secara eksplisit dan tegas yang tertuang dalam visi dan misi perusahaan, sedangkan pada bank konvensional tidak secara tegas. (Hasbi, 2019)

Berdasarkan konsep ekonomi Islam, dalil-dalil dalam Al-Qur'an diantaranya surat Al-Baqarah ayat 267, At-Taubah ayat 103, dan hadist Nabi Muhammad SAW dijadikan sebagai pijakan dalam keharusan perbankan syariah untuk mengeluarkan zakat sebesar ketentuannya. Kewajiban zakat sangat terkait dengan perusahaan dinyatakan pada muktamar internasional pertama tentang zakat di Kuwait (29 Rajab 1404 H). Menurut hasil muktamar, perusahaan dikategorikan sebagai syakhsan i'tibaran (badan hukum yang dianggap orang) atau syakhsiyyah hukmiyyah karenanya perusahaan termasuk muzakki atau subjek zakat (Rofiq, 2021).

Secara bentuk yang lebih operasional, metafora "amanah" bisa diturunkan menjadi metafora "zakat" atau realitas organisasi yang dimetaforakan dengan zakat (a zakat methsphorarised organisational reality), artinya bahwa organisasi bisnis orientasinya tidak hanya lagi profit oriented, atau stakeholder oriented, tetapi juga zakat oriented.

Zakat yang diwajibkan atas badan usaha (perusahaan) tidak dimaksudkan untuk membebani badan usaha secara berlebihan dan mengancam sustainabilitas perusahaan. Berdasarkan Undang-undang No. 17/2000 atau disebut juga UndangUndang PPh pasal 4 ayat 3, pengeluaran zakat dinyatakan sebagai pengurang penghasilan kena pajak yang mengeluarkan zakat. Namun demikian bank syariah sebagai lembaga bisnis tentunya akan mempertimbangkan kondisi kinerja keuangannya salah satunya ialah rasio profitabilitas dalam melakukan kebijakan apapun termasuk mengeluarkan zakat. Profitabilitas merupakan rasio untuk menilai kemampuan perusahaan dalam memperoleh keuntungan (laba), rasio ini juga memberikan ukuran efektivitas manajemen dan efisiensi perusahaan (Iswanaji et al, 2021).

Untuk meningkatkan kemampuan zakat perusahaan harus terlebih dahulu meningkatkan kinerja perusahaan. Dengan demikian jika dengan kinerja keuangan baik maka bank akan cenderung mengeluarkan zakat sesuai dengan ketentuan Undang-Undang dan agama. Untuk mengetahui perhitungan dana zakat dan kinerja perusahaan diperlukan adanya laporan keuangan secara umum yang sudah berlaku. Pola perhitungan zakat perusahaan adalah didasarkan pada laporan keuangan (neraca) perusahaan, dengan cara sederhana adalah dengan 
mengurangkan kewajiban lancar atas aktiva lancar (Dendawijaya, 2003).

Dalam menjaga tingkat profitabilitasnya, maka bank harus tetap menjaga tingkat likuiditasnya. Apabila bank mempunyai asseet likuid yang besar jumlahnya, maka tingkat profitabilitasnya dapat terganggu. Dengan ini berarti bahwa untuk tingkat profitabilitas bank dapat ditunjukkan berdasarkan besarnya Return On Asset (ROA) dan Return On Equity (ROE). Sedangkan tingkat likuiditas dapat ditunjukkan berdasarkan besarnya loan to deposit ratio dan loan on asset ratio Hasbi \& Amin, 2021).

Ukuran profitabilitas pada industri perbankan yang digunakan pada umumnya adalah Return On Assets (ROA) dan Return On Equity (ROE). ROA memfokuskan pada kemampuan perusahaan untuk memperoleh earning dalam operasinya, sedangkan ROE hanya mengukur return yang diperoleh dari investasi pemilik perusahaan dalam bisnis tersebut.

\section{TINJAUAN PUSTAKA Rasio Profitabilitas}

Rasio profitabilitas atau biasa disebut dengan istilah rentabilitas adalah kemampuan suatu perusahaan, untuk menghasilkan laba selama periode tertentu. Analisis profit ini mencerminkan tingkat efektifitas yang dicapai oleh usaha operasional perusahaan. Seperti halnya, rasio profitabilitas merupakan salah satu dari rasio-rasio keuangan dalam mengukur kinerja (performance) perusahaan atau bank dalam mengelola hasilnya secara operasional, rasio ini juga mengukur efektifitas manajemen secara keseluruhan yaang ditunjukan oleh besar kecilnya tingkat keuntungan yang diperoleh dengan penjualan maupun investasi (Kasmir, 2014)

\section{Return On Asset (ROA)}

Return On Asset digunakan untuk mengetahui kemampuan manajemen bank dalam mengelola aset, guna menghasilkan keuntungan laba bersih. (Sartono, 2001)

ROA yaitu indikator kemampuan perbankan utuk memperoleh laba atas sejumlah aset yang dimiliki oleh bank. Semakin besar ROA maka semakin besar tingkat keuntungan yang dicapai oleh perusahaan tersebut dan semakin baik juga dari penggunaan assets oleh perusahaan tersebut (Sholihin, 2010)

ROA dapat diperoleh dengan cara menghitung rasio antara laba dengan total aktiva, sebagai berikut:

$$
\begin{aligned}
& \text { ROA } \\
& =\frac{\text { Laba Bersih Sebelum Pajak }}{\text { Total Asset }} \times 100
\end{aligned}
$$

\section{Return On Equity (ROE)}

Return On Equity yang digunakan untuk mengukur kemampuan manajemen bank dalam mengelola capital yang ada guna memperoleh keuntungan Rasio ROE penting bagi para pemilik dan pemegang saham. Semakin tinggi ROE maka semakin tinggi tingkat laba yang dihasilkan karena penambahan modal kerja dapat digunakan untuk membiayai operasi perusahaan yang hasilnya dapat menghasilkan laba.

Dengan kata lain, semakin tinggi rasio ini maka semakin baik artinya posisi pemilik perusahaan semakin kuat. Keadaan tersebut dapat mempengaruhi minat para investor untuk melakukan transaksi jual beli saham sehingga akan meningkatkan volume penjualan saham perusahaan (Siamat, 2005).

ROE yaitu indikator kemampuan perbankan dalam mengelola modal yang tersedia untuk mendapatkan laba bersih. ROE dapat diperoleh dengan cara 
menghitung rasio antara laba dengan total ekuitas, sebagai berikut:

$$
\text { ROE }=\frac{\text { Laba Bersih Setelah Pajak }}{\text { Total Modal }}
$$

\section{Zakat Perusahaan}

Zakat perusahaan menurut konsep entitas adalah suatu konsep yang memberikan pandangan mengenai suatu unit usaha, organisasi atau kelembagaan yang mempunyai tanggung jawab (hak dan kewajiban) di depan hukum terpisah dari tanggung jawab para pemiliknya dalam menjalankan setiap usahanya (Mufraini, 2012).

Ketentuan-ketentuan zakat perusahaan menurut Muhammad (2005) adalah:

a. Berjalan satu tahun (haul) yaitu dengan menggabungkan semua harta perdagangan awal dan akhir dalam satu tahun kemudian dikeluarkan zakatnya.

b. Mencapai nishab perdagangan, sama dengan nishab emas yaitu senilai 85 gram emas.

c. Kadarnya zakat sebesar $2,5 \%$.

\section{Penelitian Terdahulu}

Zaitun (2001) melakukan penelitian berjudul "Analisis Pengaruh Rasio Profitabilitas Terhadap Zakat Pada PT. Bank Muamalat Indonesia". Hasil penelitian menunjukkan bahwa rasio-rasio profitabilitas mempunyai pengaruh dominan terhadap zakat. Variabel-variabel independent yang terdiri dari ROA dan ROE secara bersama-sama mempunyai pengaruh yang secara statistik signifikan terhadap zakat.

Muammar (2010) melakukan penelitian berjudul "Analisis Pengaruh Kinerja Keuangan Terhadap Kemampuan Zakat Pada Bank Syariah Mandiri Dan Bank Mega Syariah". Hasil penelitian menunjukkan bahwa rasio profitabilitas yang diukur dengan ROA dan ROE secara simultan dan parsial berpengaruh signifikan terhadap kemampuan zakat.

Firmansyah dan Rusydiana (2013) melakukan penelitian berjudul "Analisis Pengaruh Profitabilitas Terhadap Pengeluaran Zakat Pada Bank Umum Syariah Di Indonesia Dengan Ukuran Perusahaan Sebagai Variabel Moderasi". Dari hasil penelitian menyatakan bahwa rasio profitabilitas diukur dengan Return On Asset (ROA) yang dimoderasi dengan ukuran perusahaan berpengaruh positif terhadap pengeluaran zakat.

Sari (2014) melakukan penelitian berjudul "Pengaruh Rasio Profitabilitas Terhadap Pengeluaran Zakat PT. Bank Syariah Mandiri Di Indonesia Periode 2010-2012". Dari hasil penelitian menyatakan bahwa Return On Asset (ROA) tidak berpengaruh terhadap pengeluaran zakat pada PT Bank Syariah Mandiri. Sedangkan Return On Equity (ROE) berpengaruh positif signifikan terhadap pengeluaran zakat pada PT. Bank Syariah Mandiri.

Jayanti et al, (2015) melakukan penelitian berjudul "Pengaruh Kinerja Keuangan Terhadap Zakat Bank Umum Syariah Yang Terdaftar Di Bank Indonesia Periode 2010-2014". Dari hasil penelitian menunjukkan bahwa kinerja keuangan yang diukur dengan ROA, ROE, BOPO, dan NIM berpengaruh secara simultan terhadap zakat.

\section{METODE PENELITIAN}

Penelitian ini menggunakan data sekunder yang diperoleh dari laporan keuangan yang dipublikasikan oleh perusahaan. Data sekunder merupakan sumber data penelitian yang diperoleh peneliti secara tidak langsung melalui media perantara dieroleh dan dicatat oleh pihak lain.

Penelitian ini menggunakan penelitian kuantitatif berupa data panel 
yang terdiri dari time series selama 4 tahun yaitu 2014-2017 dan data cross section sebanyak 4 bank umum syariah yang terdaftar sebagai Bank Umum Swasta Nasional (BUSN) Devisa (Indrianto dan Supomo, 2014).

Sumber data pada penelitian ini merupakan data sekunder dalam berupa laporan keuangan tahunan (annual report) yang dikumpulkan melalui website resmi masing-masing bank syariah yang bersangkutan yaitu pada empat sumber data.

Dalam penelitian ini, metode analisis yang digunakan untuk menganalisis return on asset dan return on equity terhadap tingkat kemampuan zakat pada bank umum syariah yang terdaftar sebagai Bank Umum Swasta Nasional (BUSN) Devisa selama periode 2014-2017 adalah analisis statistik deskriptif (Sugiyono, 2010)

Tabel 1. Daftar Bank Umum Syariah

\begin{tabular}{cc}
\hline NO & NAMA BANK SYARIAH \\
\hline 1 & PT Bank Muamalat Indonesia (BMI) \\
\hline 2 & PT BNI Syariah (BNIS) \\
\hline 3 & PT Bank Syariah Mandiri (BSM) \\
\hline
\end{tabular}

Sedangkan untuk mengetahui keterkaitan antara return on asset dan return on equity terhadap tingkat kemampuan zakat pada bank umum syariah yang terdaftar sebagai Bank Umum Swasata Nasional (BUSN) Devisa selama periode 2014-2017 menggunakan analisis data panel dengan alat bantu berupa software Eviews 9.

\section{HASIL PENELITIAN}

Penelitian ini dimaksudkan untuk menganalisis pengaruh antara Return On Assets (ROA) dan Return On Equity (ROE) terhadap tingkat kemampuan pengeluaran zakat. Dalam penelitian ini peneliti memilih bank umum syariah yang termasuk dalam kategori Bank Umum Swasta Nasional (BUSN) Devisa selama periode 2014-2017. Selain itu, bank umum syariah yang diteliti adalah yang mempublikasikan laporan keuangan secara rutin per 31 Desember dan sudah diaudit, serta melaporkan keuangannya menggunakan kurs rupiah. Dari kriteria yang ditetapkan oleh peneliti tersaring 4 bank umum syariah yang menjadi objek penelitian.

Berdasarkan data yang sudah dipaparkan oleh peneliti, selanjutnya dilakukan statistik deskriptif yang disajikan pada tabel di bawah ini:

Tabel 2. Statistik Deskriptif

\begin{tabular}{lccc}
\hline & ZAKAT & ROA & ROE \\
\hline Mean & 3703721. & 0.009177 & 0.044849 \\
\hline Median & 2599426. & 0.008305 & 0.021614 \\
\hline Maximum & 10218675 & 0.024146 & 0.126131 \\
\hline Minimum & -641955.1 & -0.000384 & -0.009706 \\
\hline Std. Dev. & 3597755. & 0.008145 & 0.043832 \\
\hline Skewness & 0.705438 & 0.560477 & 0.682665 \\
\hline Kurtosis & 2.073001 & 2.099236 & 1.925008 \\
\hline Jarque-Bera & 1.899933 & 1.378610 & 2.013154 \\
\hline Probability & 0.386754 & 0.501925 & 0.365468 \\
\hline
\end{tabular}


2021, Jurnal Tabarru' : Islamic Banking and Finance 4 (2) : 488 - 498

\begin{tabular}{lccc}
\hline Sum & 59259532 & 0.146835 & 0.717577 \\
\hline Sum Sq. Dev. & $1.94 \mathrm{E}+14$ & 0.000995 & 0.028818 \\
\hline Observations & 16 & 16 & 16 \\
\hline Cross sections & 4 & 4 & 4 \\
\hline \multicolumn{4}{l}{ Sumber : Data Olahan (2017) } \\
\end{tabular}

Zakat perusahaan seperti hukum zakat perdagangan karena perusahaan memproduksi dan kemudian menjualnya, atau menjadikan apa yang produksinya sebagai komoditas perdagangan maka perusahaan harus mengeluarkan zakat apabila jumlah telah mencapai nishab yaitu 85 gram emas murni, maka kemudian dipungut zakat sebesar $2,5 \%$. Pada Tabel 2 diketahui bahwa nilai zakat hitung memiliki nilai rata-rata sebesar Rp. 3.703.721.000, dengan nilai tengah sebesar Rp. 2.599.426.000 dan standar deviasi sebesar Rp. 3.597.755.000. Zakat tertinggi adalah sebesar Rp. 10.218.675.000 dimana berasal dari PT. BNI Syariah tahun 2017 dan ketidak mampuan dalam pengeluaran zakat sebesar Rp. 641.955.100 berasal dari PT. Bank Syariah Mandiri pada tahun 2014.

Rasio ROA digunakan untuk mengukur kemampuan manajemen dalam memperoleh keuntungan (laba) secara keseluruhan. Semakin besar ROA semakin besar pula tingkat keuntungan yang dicapai oleh perusahaan tersebut dan semakin baik pula perusahaan tersebut dari segi penggunaan aset. ROA mengukur sejauh mana kemampuan perusahaan dalam menghasilkan laba bersih dari total aset yang dimiliki. Pada Tabel 2 dapat dilihat bahwa nilai ROA memiliki nilai rata-rata sebesar $0,9 \%$ dengan nilai tengah $0,8 \%$ dan standar deviasinya sebesar $0,8 \%$. ROA tertinggi sebesar 2,4\% berasal dari PT. Bank Syariah Mandiri pada tahun 2017 sedangkan ROE terendah sebesar $-0,04 \%$ berasal dari PT. Bank Syariah Mandiri pada tahun 2014.

\section{HASIL DAN PEMBAHASAN}

\section{Pemilihan Model Regresi Data Panel}

Dalam regresi data panel terdapat tiga model regresi yang dapat dipilih yaitu common effect, fixed effect, dan random effect. Untuk memilih model regresi yang paling tepat dapat dilakukan dengan melakukan uji chow dan uji hausman.

\section{Uji Chow}

Uji chow bertujuan untuk memilih model antara common effect atau fixed effect. Untuk mengetahui model mana yang terpilih dengan cara membandingkan nilai signifikansi dengan nilai probabilitas cross-section chi-square. Apabila nilainya melebihi >0,05 (5\%) maka model yang terpilih adalah common effect, jika $<0,05$ (5\%) maka model yang terpilih adalah fixed effect. Dengan demikian diketahui bahwa nilai probabilitas cross-section chisquare adalah 0,0006 atau dengan kata lain, memiliki nilai probabilitas yang lebih kecil daripada nilai signifikansi 0,05 (5\%), sehingga dapat disimpulkan bahwa model regresi yang paling tepat pada penelitian ini adalah fixed effect.

\section{Uji Hausman}

Uji Hausman dilakukan untuk memilih model mana yang lebih baik antara fixed effect atau random effect. Pengujian ini dilakukan dengan cara membandingkan antara nilai probabilitas cross-section random lebih kecil dari 0,05 maka model yang terpilih adalah fixed effect, sebaliknya jika nilai probabilitas cross-section random lebih besar dari 0,05 maka model yang terpilih adalah random effect. Dengan demikian diketahui bahwa nilai probabilitas cross-section random adalah 0,8553 atau dengan kata lain, memiliki nilai probabilitas yang lebih 
besar dari nilai signifikansi $0,05(5 \%)$, sehingga dapat disimpulkan bahwa model regresi yang paling tepat untuk menjadi model regresi pada penelitian ini adalah random effect

\section{Pengujian Hipotesis}

\section{Koefisien Determinasi $\left(\mathbf{R}^{2}\right)$}

Nilai koefisien determinasi (R2) digunakan untuk mengukur seberapa jauh kemampuan model dalam menerangkan variasi variabel dependen. Nilai koefisien determinasi adalah antara nol sampai satu, semakin nilai R2 mendekati satu maka variabel-variabel independen memberikan hampir semua informasi yang dibutuhkan untuk memprediksi variasi variabel independen.

Dapat diketahui bahwa adjusted $R$ square menunjukkan nilai sebesar 0,628678, hal ini dapat diartikan bahwa variabel-variabel penelitian yang digunakan dalam penelitian ini diantaranya return on asset dan return on equity secara bersama-sama berpengaruh atau dapat menjelaskan terhadap kemampuan pengeluaran zakat sebesar $63 \%$, sedangkan sisanya $37 \%$ dapat dijelaskan oleh variabel-variabel lain di luar variabel independen dalam penelitian ini.

\section{Uji Statistik F (Uji Signifikansi Simultan)}

Uji $F$ bertujuan untuk menunujukkan apakah semua variabel independen yang dimasukkan dalam model mempunyai pengaruh secara bersama-sama atau simultan terhadap variabel dependen. Hal ini dapat diketahui dengan cara membandingkan antara nilai probabilitas f-statistik dengan nilai signifikansi $0,05 \quad(5 \%)$. Apabila nilai probabilitas yang didapatkan lebih kecil dari nilai signifikansi 0,05 maka dapat diartikan bahwa secara simultan variabel independen mempengaruhi variabel dependen.
Dapat diketahui bahwa nilai probabilitas f-statistik sebesar 0,000630 hal ini dapat diartikan bahwa variabelvariabel independen pada penelitian ini berupa return on asset dan return on equity secara simultan berpengaruh terhadap kemampuan pengeluaran zakat (Ho ditolak dan $\mathrm{Ha}$ diterima). Hal ini karena nilai probabilitas lebih kecil dari nilai signifikansi 0,05 . Hasil uji $f$ ini juga menunjukkan bahwa faktor-faktor yang mempengaruhi kemampuan pengeluaran zakat yang diusulkan oleh Muammar (2010) secara simultan dapat terbukti.

\section{Uji Statistik $\mathbf{T}$ (Uji Signifikansi Parameter Individu)}

Uji statistik $\mathrm{T}$ bertujuan untuk menunjukkan pengaruh variabel independen secara parsial atau dengan menganggap variabel independen lainnya konstan. Untuk mengetahui pengaruh variabel independen secara parsial atau uji $t$ dapat dilakukan dengan cara membandingkan nilai probabilitas dengan nilai signifkansi 0.05 (5\%). Apabila nilai probabilitas lebih kecil dari nilai signifikansi 0,05 maka variabel independen.

Berdasarkan hasil pengolahan data yang telah dilaksanakan maka diperoleh persamaan regresi. Dari hasil regresi dapat disederhanakan menjadi persamaan model regresi yang berfungsi untuk menganalisa variabel independen terhadap variabel dependen. Pada penelitian ini variabel dependen yang digunakan adalah zakat sedangkan variabel independen pada penelitian ini adalah return on asset dan return on equity.

Adapun persamaan model regresi random effect dinyatakan sebagai berikut:

$\mathrm{ZAK}=646778.2+1.29 \mathrm{E}+08 \mathrm{ROA}+4178029$ $2 \mathrm{ROE}+\mathrm{e} . . . .(4.1)$ 


\section{Konstanta $\left(\boldsymbol{\beta}_{1}\right)$}

Nilai Konstanta $\left(\beta_{1}\right)$ dari Zakat sebesar 646778,2. Hasil ini dapat diartikan bahwa apabila variabel ROA dan ROE sama dengan nol, maka nilai Zakat sebesar 646778,2.

\section{ROA}

Variabel Rasio Profitabilitas yang diproksikan dengan Return On Asset (ROA) memiliki nilai koefisien sebesar 1,29E+08. Sedangkan probabilitas menunjukkan nilai $0,1405>\alpha=5 \%(0,05)$. Jadi hubungan ROA terhadap kemampuan pengeluaran zakat adalah tidak berpengaruh. Maka apabila terjadi kenaikan $1 \%$ pada ROA tidak akan meningkatkan kemampuan pengeluaran zakat karena hubungan diantara keduanya berpengaruh positif dan tidak signifikan.

Hasil penelitian ini sejalan dengan penelitian Sari (2014), bahwa Return On Asset (ROA) tidak berpengaruh terhadap pengeluaran zakat. Hasil ini dimungkinkan karena nominal zakat dalam penelitian ini dihitung berdasarkan laba perusahaan saja dan return on asset dihitung dengan rumus laba sebelum pajak dibagi total aset, sementara itu dalam komponen total aset terdapat asetaset pengurang zakat contohnya ialah aset tetap. Aset dapat diklasifikasikan menjadi dua macam yaitu yang membawa kenaikan pada kemampuan pengeluaran zakat atau menurunkannya. Hal tersebut dapat dijelaskan dari formulasi zakat karena faktor aktiva akan membuat zakat turun bila itu merupakan aset tetap tetapi apabila merupakan aset lancar sebaliknya akan meningkatkan dana zakat. Faktor lain yang memiliki kemungkinan akan terjadinya hal ini antara lain kinerja manajemen dalam menggunakan aset perusahaan yang dimiliki belum bisa dikelola secara efektif dan efisien yang menyebabkan laba bersih yang dihasilkan menjadi kecil sedangkan aset yang dimiliki oleh perusahaan sangat besar.

\section{ROE}

Variabel Rasio Profitabilitas yang diproksikan dengan Return On Equity (ROE) memiliki nilai koefisien sebesar 41780292 sedangkan probabilitas menunjukkan nilai $0,0331<\alpha=5 \%(0,05)$. Jadi hubungan ROE terhadap kemampuan pengeluaran zakat adalah berpengaruh. Maka apabila terjadi kenaikan $1 \%$ pada ROE akan mengalami peningkatan kemampuan pengeluaran zakat sebesar 41780292 karena hubungan diantara keduanya berpengaruh positif dan signifikan.

Hasil penelitian inirelevan dengan penelitian-penelitian terdahulu Zaitun (2000), menyatakan bahwa Return On Equity berpengaruh positif signifikan terhadap pengeluaran zakat karena semakin tinggi ROE semakin tinggi pula tingkat laba yang dihasilkan, karena penambahan modal kerja dapat digunakan untuk membiayai operasi perusahaan yang hasilnya dapat menghasilkan laba. Dengan kata lain perusahaan yang memiliki Return On Equity baik atau bahkan meningkat akan terklarifikasi sebagai perusahaan yang baik dalam menghasilkan pendapatannya. Semakin tingginya laba bank yang ditunjukkan oleh tingginya ROE nya maka kemampuan bank dalam mengeluarkan zakat akan semakin baik sebab laba dinilai sebagai pertambahan harta oleh karenanya digolongkan sebagai harta yang harus dizakati.

\section{KESIMPULAN}

Variabel Return On Asset ROA) secara statistik tidak berpengaruh terhadap tingkat kemampuan pengeluaran zakat bank syariah devisa dibuktikan dengan hasil temuan probabilitas. Maka hubungan Return On Asset (ROA) terhadap kemampuan pengeluaran zakat pada bank syariah devisa tidak berpengaruh. Variabel Return On Equity (ROE) secara statistik berpengaruh positif terhadap 
tingkat kemampuan pengeluaran zakat bank syariah devisa dibuktikan dengan hasil temuan probabilitas dan nilai koefisien. Maka hubungan Return On Equity (ROE) terhadap kemampuan pengeluaran zakat bank syariah devisa berpengaruh positif dan signifikan sesuai hipotesis

\section{DAFTAR PUSTAKA}

Antonio, Muhammad Syafi'i. 2005. Bank Syariah dari Teori ke Praktek. Gema Insani. Jakarta.

Dendawijaya, Lukman. 2003. Manajemen Perbankan. Ghallia Indonesia. Jakarta.

Firmansyah, Irman, dan Rusydiana, Aam S. 2013. Analisis Pengaruh Profitabilitas Terhadap Pengeluaran Zakat Pada Bank Umum Syariah Di Indonesia Dengan Ukuran Perusahaan Sebagai Variabel Moderasi. Jurnal Liquidity, 2(2), p. 110-116.

Hasbi, M. Zidny Nafi' \& Amin, Muhammad. 2021. Analisis Pengaruh Rasio Profitabilitas Terhadap Tingkat Kemampuan Pengeluaran Zakat Pada BUSN Devisa. Jurnal Akuntansi Manajemen Bisnis dan Teknologi, 1(2), p. 89-102.

Hasbi, M. Zidny Nafi'. 2019. Dampak Krisis Keuangan Global Terhadap Perbankan Di Indonesia. LISAN AL-HAL: Jurnal Pengembangan Pemikiran Dan Kebudayaan, 13(2), p. 385-400.

Indriantoro, Nur., \& Supomo, Bambang. 2014. Metodologi Penelitian Bisnis Untuk Akuntansi dan Manajemen. Edisi Pertama. BPFE. Yogyakarta.

Iswanaji, Chaidir., Hasbi, M. Zidny Nafi'., Salekhah, Fitri., \& Amin, Muhammad. 2021. Implementasi
Analitycal Networking Process (ANP) Distribusi Zakat Terhadap Pembangunan Ekonomi Masyarakat Berkelanjutan (Studi Kasus Lembaga Baznas Kabupaten Jember Jawa Timur). Jurnal Tabarru': Islamic Banking and Finance, 4(1), p. 195-208.

Iswanaji, Chaidir., Khotijah, Siti Afidatul., \& Hasbi, M. Zidny Nafi'. 2021. Lembaga Keungan Syariah (Buku Ajar Konsentrasi Syariah). Penerbit Adab. Jawa Barat.

Jayanti, Tri Winda., Khairani, Siti., \& Pratiei, Raisa. 2015. Pengaruh Kinerja Keuangan Terhadap Zakat Bank Umum Syariah Yang Terdaftar Di Bank Indonesia Periode 2010-2014. Jurnal Penelitian. Program Studi Akuntansi STIE MDP Palembang.

Kasmir. 2004. Manajemen Perbankan. PT Raja Grafindo Persada. Jakarta.

Muammar, Ahmad Nurul. 2010. Analisis Pengaruh Kinerja Keuangan Terhadap Kemampuan Zakat Pada Bank Syariah Mandiri Dan Bank Mega Syariah. Skripsi. IAIN Walisongo. Semarang.

Mufraini, Arif. 2012. Akuntansi dan Manajemen Zakat: Mengkomunikasikan Kesadaran dan Membangun Jaringan. Kencana. Jakarta.

Muhammad. 2005. Manajemen Bank Syariah. UPP AMP YKPN. Yogyakarta.

Rofiq, Nur. 2021. Implementasi Akad Bai Bitsaman Ajil Pada BMT UGT (Usaha Gabungan Terpadu Sidogiri Cabang Pembantu Asembagus Situbondo) Perspektif Hukum Islam. Literasi Hukum, 5(2), p. 81-87. 
Sari, Wana Asvera. 2014. Pengaruh Rasio Profitabilitas Terhadap Pengeluaran Zakat PT Bank Syariah Mandiri Di Indonesia Periode 2010-2012. Skripsi. UIN Sultan Syarif Kasim. Riau

Sartono, Agus. 2001. Manajemen Keuangan: Teori dan Aplikasi. BPFE-Yogyakarta. Yogyakarta.

Sholihin, Ahmad Ifham. 2010. Pedoman Lembaga Keuangan Syari'ah. Gramedia. Jakarta.

Siamat, Dahlan. 2005. Manajemen Lembaga Keuangan, Edisi Keempat. Badan Penerbit Fakultas Ekonomi Indonesia. Jakarta.

Sugiyono. 2010. Statistika Untuk Penelitian. Alfabeta. Bandung.

Zaitun, Sri. 2001. Analisis Pengaruh Rasio Profitabilitas Terhadap Zakat Pada PT. Bank Muamalat Indonesia. Tesis. Program Studi Magister Manajemen Universitas Diponegoro. Semarang. 